\title{
Variation in Preposition Use in the Virgin Islands Dutch Creole (VIDC) Cluster
}

\author{
Pieter Muysken, Cefas van Rossem and Robbert van Sluijs \\ Centre for Language Studies, Radboud Universiteit \\ Corresponding author: p.muysken@let.ru.nl
}

\begin{abstract}
There is a growing consensus that the varieties of Virgin Islands Dutch Creole (VIDC) often referred to as Negerhollands - should not be viewed as a single language, but rather as a language cluster of related varieties. However, there has been only limited systematic comparison of the varieties in the cluster as to their structural characteristics. We will try to fill this gap in this chapter by charting a specific construction: the supra-locative prepositional phrases in two varieties of VIDC: the 20th century data recorded by Josselin de Jong and the variety in the 18th century religious texts. A systematic search in the VIDC data is possible because of the data base constructed for this language with the support of Clarin-NL. We will try to contrast the feature studied with those found in 17th century Dutch informal writings and in two relevant West-African languages: Akan and Ewegbe. The theoretical model used here derives from the notion of feature pool.
\end{abstract}

\subsection{Introduction}

There is a growing consensus that the varieties of Virgin Islands Dutch Creole (VIDC) - often referred to as Negerhollands - should not be viewed as a single language, but rather as a language cluster of related varieties (Muysken 1995; Van Rossem and Van der Voort 1996; Sabino 2012; see also Van Sluijs et al., 2016), which also show considerable internal variation (Van Sluijs 2016). However, there has been only limited systematic comparison of the varieties in the cluster as to their structural characteristics. Building in part on Bakker (2014), we will try to fill this gap in this chapter by charting a specific construction: the supra-locative prepositional phrase of the type $((n) a) b o(n o)$ 'on' in two varieties of VIDC: the 20th century data recorded by Josselin de Jong (1926), and the

\section{How to cite this book chapter:}

Muysken, P, van Rossem, C and van Sluijs, R. 2017. Variation in Preposition Use in the Virgin Islands Dutch Creole (VIDC) Cluster. In: Odijk, J and van Hessen, A. (eds.) CLARIN in the Low Countries, Pp. 133-149. London: Ubiquity Press. DOI: https://doi.org/10.5334/bbi.12. License: CC-BY 4.0 
variety in the 18th century religious texts. A systematic search in the VIDC data is possible because of the NEHOL data base constructed for this language with the support of Clarin-NL. We will try to contrast the feature studied with those found in 17th century Dutch informal writings and in two relevant West-African languages: Akan and Ewegbe.

The theoretical framework adopted here involves the notion of 'feature pool' (Mufwene 2001). In this framework, creole languages are constructed out of a number of possible features and elements available in the multilingual speech community in which the creole emerged: the so-called feature pool. This framework is interesting for us because the VIDC cluster contains 'layers', corresponding to the various lects in the complex early community and to the various 'authors' of texts. Regarding the variable involved here there exist:

(a) a 'Dutch' layer of simple prepositions, including op 'on' and boven 'above';

(b) an 'Atlantic creole' layer including the general locative preposition $n a$;

(c) West-African substrate patterns which include $[\mathrm{NP}+$ LOCATION $]$ and [LOC $+\mathrm{NP}+$ LOCATION].

In the extant corpus these layers compete, and have a variable distribution.

In section 12.2 we briefly mention some points in the history of VIDC and briefly discuss the sources. Section 12.3 focuses on the variable: prepositions in VIDC. In section 12.4 Atlantic na and possible substrate influence is discussed, and in section 12.5 relevant preposition use in $17^{\text {th }}$ century Dutch. Sections 12.6 and 12.7 present the findings for $18^{\text {th }}$ and $20^{\text {th }}$ century VIDC, followed by some discussion, conclusions and suggestions in section 12.8 .

\subsection{VIDC: History and Sources}

Here we briefly mention some points in the history of VIDC, referring the reader to Van Sluijs (2016) and Van Rossem (2017) for further detail.

\subsubsection{History}

While St. Thomas was probably inhabited by Arawakan groups since 300 BC, in 1672 the first European settlers arrived at what then became the Danish Antilles. However, many settlers did not come from Denmark, and particularly settlers from Zealand and Flanders were dominant in the new colony, which soon became a plantation colony. In 1673 enslaved Africans started being imported, particularly from Ghana. Around 1700 there must have been a nascent Creole language with Flemish and Zealandic as the main lexifier varieties. Caribbean Dutch functioned as a lingua franca in the colony, and the Moravian missionary community started using the creole. In fact, in 1736 there is the first mention in any Caribbean source of the term Carriolsche 'Creole' for the language, as we find the first intentions use VIDC as a missionary language. The language flourished throughout the colony through much of the $18^{\text {th }}$ century, but by 1843 English Creole has largely replaced VIDC.

\subsubsection{Documentation and Sources}

There is a rich array of $18^{\text {th }}$ century sources, which require, however, considerable philological interpretation (Van Rossem 2017). In 1742 the first printed texts appeared on the island with traces of VIDC, and from that year until 1843 there has been a steady stream of missionary translations into VIDC by the Moravian Brethren and the Danish Lutheran Church. There are also letters of enslaved Africans from the early period, partly in Dutch, partly in VIDC. The first printed grammar of any creole language is also about VIDC and dates from 1770, by J.M. Magens. Oldendorp's (1777) manuscript grammar dates from 1770 as well, and was first printed in a shorter version 
(the complete version appeared as Oldendorp 2000: 681-724). His dictionary is from 1767/68 (Stein 1996). An anonymous grammar written by Moravian Brethren at the beginning of the $19^{\text {th }}$ century was used by Hesseling (1905). Internationally, VIDC started being studied in 1805 when the historical linguist Rask made a typological comparison of Greenland Inuit and VIDC. In 1871 Van Name compared VIDC to other Caribbean creoles and in 1881/1887 Pontoppidan published his contributions. Hesseling published his anthology of historical sources and $18^{\text {th }}$ century texts in 1905, and in 1922-1923 De Josselin de Jong carried out fieldwork among speakers of whom he thought would be the last ones. However in 1936 Nelson unexpectedly had the opportunity to still compile a word list after interviewing speakers of Dutch Creole, which was used by Reinecke (1937).

In the 1960-80s fragments of the language as remembered by the last speakers were recorded by Sprauve (1976), Adams Graves (1977), and Sabino (1990). The demise of Alice Stevens in 1987 marked the end of the spoken language.

Starting around 1980 and until now 2015, a group initially inspired by the work of Peter Stein and later involving Hans den Besten and Pieter Muysken (who together supervised Hein van der Voort and Cefas van Rossem) started exploring the missionary archives. This led to various book publications (e.g. van der Voort and van Rossem 1996; Stein and van der Voort (1996), and much of the digitalized material was made available electronically via the NEHOL database with the financial and technical support of Clarin-NL through the work of Robbert van Sluijs.

The eighteenth century VIDC texts that were used are given in Table 12.1.

For $17^{\text {th }}$ and $18^{\text {th }}$ century Dutch we used the intercepted letters in Dutch written by seamen and colonists in the $17^{\text {th }}$ and $18^{\text {th }}$ centuries and kept in British National Archives in Kew Gardens

\begin{tabular}{|c|c|c|c|}
\hline Text & Date & Clarin & Characteristics \\
\hline $\begin{array}{l}\text { Zinzendorf Farewell } \\
\text { Letter }\end{array}$ & 1739,1742 & 3.1 .1 & $\begin{array}{l}\text { First known text written in } \\
\text { VIDC, translation of }\end{array}$ \\
\hline $\begin{array}{l}\text { Gebeden en Liederen } \\
\text { voor die swart Broeder- } \\
\text { Gemeenten na S. } \\
\text { Thomas, S. Croix en S. } \\
\text { Jan. }\end{array}$ & 1765 & HERRN65A & $\begin{array}{l}\text { First printed hymnbook in } \\
\text { VIDC by the Moravian } \\
\text { Brethren }\end{array}$ \\
\hline Gospel Harmony 321 & Around 1773 , before 1780 & $3.2 .1 \_1 \_35$ & $\begin{array}{l}\text { First } 35 \text { sections of } \\
\text { translation of S. } \\
\text { Lieberkühn's Gospel } \\
\text { Harmony by Moravian } \\
\text { missionary J. Böhner }\end{array}$ \\
\hline Gospel Harmony 322 & Around 1780 & 3.2.1_1_35 & $\begin{array}{l}\text { First } 35 \text { sections of second } \\
\text { translation of Gospel } \\
\text { Harmony by J. Böhner }\end{array}$ \\
\hline Gospel Harmony 3231 & Around 1790 & 3231_1_35 & $\begin{array}{l}\text { First } 35 \text { sections of Gospel } \\
\text { Harmony, edited and } \\
\text { written by J.C. Auerbach }\end{array}$ \\
\hline Gospel Harmony 3232 & Around 1795 & 3232_1_35 & $\begin{array}{l}\text { First } 35 \text { sections of Gospel } \\
\text { Harmony, Unfinished } \\
\text { manuscript, probably used } \\
\text { for printed Gospel } \\
\text { Harmony (1833) }\end{array}$ \\
\hline Old Testament & Between 1780 and 1785 & 325 & $\begin{array}{l}\text { Translation of the Old } \\
\text { Testament into VIDC }\end{array}$ \\
\hline
\end{tabular}

Table 12.1: $18^{\text {th }}$ century sources used for VIDC. 
(Rutten and Van der Wal 2014). For $20^{\text {th }}$ century VIDC we used the recorded fieldwork stories of Jossselin de Jong (1926)

\subsection{Prepositions in VIDC}

Since this chapter focuses on locative prepositions, we provide some general remarks on locative prepositions and some background information on prepositions in VIDC.

\subsubsection{Prepositions in Creoles: Analytical Framework}

Following Vandeloise (1991, 1994) and Zribi-Hertz (1984), Zribi-Hertz and Loïc (2015) distinguish +/- configurational locatives to distinguish à la maison 'at home' from dans la maison 'in the house' in French. Both imply location, but only the second implies configurational location.

A further distinction is between $+/$ - functional locatives (a slightly different distinction is made by Zwarts 1997): I can go to the bank functionally, for typical banking things (e.g. to cash a check) or purely physically, to get nearer a specific building. Functional locatives are typically not configurational. Consider 'I am going home' versus 'I am going to my house'

In this chapter we focus on both configurational, and non-configurational non-functional locative prepositions in VIDC.

\subsubsection{Non-locative Prepositions}

There are a number of prepositions in VIDC, of which most have Dutch etyma (sometimes homophonous with an English source), with the exception of te:, most likely from Portuguese, listed in Table 12.2.

The most striking absent Dutch prepositions, at least in the $20^{\text {th }}$ century materials, are aan, which is dative ('to') and sometimes locative ('near') in Dutch, and Dutch te 'at'/tot 'until. There are sporadic uses of aan in the $18^{\text {th }}$ century missionary texts:

(01) zoo als Hem ha dot voor yoe an het Kruis(311)

like 3SG PST die for $2 \mathrm{SG}$ at DET.N cross

'Like He dies for you at the cross.'

(02) En as JESus a wande na $<\uparrow$ die $>$ Galile aan Zeekant $(321: 23)^{1}$

and when Jesus PST walk LOC DET Galilea at sea.side

'and when Jesus walked near Galilea at the sea side'

However, it is clear in (01) from the use of a non-VIDC neuter determiner that this is a fixed Dutch expression. For (02) the other translations of the same sentence do not have $a a n .^{2}$

\begin{tabular}{|l|l|l|}
\hline astər/-u & after & $<$ Du achter, E after \\
\hline fa(n) & of & $<$ Du van \\
\hline fo & for & $<$ Du voor \\
\hline gliek, liek & like & $<$ Du gelijk, E like \\
\hline mi/me:/met & with & $<$ Du met \\
\hline sondər/-du & without & $<$ Du zonder \\
\hline te: & until & $<$ Po até \\
\hline
\end{tabular}

Table 12.2: Non-locative prepositions in $20^{\text {th }}$ century VIDC.

1 For the notational conventions in the examples, see Van Rossem and Van der Voort (1996: XII-XIII).

2 [322: 23: En as Jesus a wandel na kant van die Galilean Zee], [3231: 23: Toen noe Jesus a wandel bij die See van Galilea]. 


\subsubsection{Locative Prepositions Without na}

A number of locative prepositions, all with Dutch etyma, are formed without $n a$ in the $20^{\text {th }}$ materials, as listed in Table 12.3.

Some of them, kan and $\mathrm{mel} / \mathrm{mid} \partial \mathrm{l}$, correspond to a noun in Dutch. In the $18^{\text {th }}$ century materials, these are combined with $n a$ and take the preposition van 'of', which is a clear indication of their nominal status at the time:

(03) En as Jesus a wandel na kant van die $\mathrm{Ga}=$ lilean Zee (322: 23) and when Jesus PST walk LOC side of DET Galilean sea 'and when Jesus walked at the side of the Galilean sea'

(04) Em set nabin die Tempel na mid=del van die Leerar-s (322: 9$)^{3}$ 3SG sit inside DET Temple LOC midst of DET teacher-PL

'He sits inside the temple in the middle of the teachers.'

\subsubsection{Locative Prepositions with na}

Finally, there is a class of prepositions that involve the non-configurational locative $n a$, which is often claimed to have a Portuguese etymon, the pro-clitic combination em $+a$ ' in +DET.F.' Configurational locatives are formed combining this $n a$ (which can be reduced to $a$ or omitted altogether) with a Dutch-etymon preposition, which is generally bisyllabic. See Table 12.4.

In this chapter we will focus exclusively on all forms related to $((n) a) b o(n o)$ 'on', from this list.

\begin{tabular}{|l|l|l|}
\hline bi & near & $<$ Du bij \\
\hline de: & through & $<$ Du door \\
\hline ini & in & $<$ Du in \\
\hline it $(\mathrm{fa})$ & out of & $<$ Du uit (van) \\
\hline kan & near, next to & $<$ Du kant 'side' \\
\hline mel/midəl & in the middle of & $<$ Du middle 'middle' \\
\hline ron & around & $<$ Du rond \\
\hline
\end{tabular}

Table 12.3: Locative prepositions without na.

\begin{tabular}{|l|l|l|}
\hline na & locative & $<$ ? Po na 'in.DET.F' \\
\hline ((n)a)astə/-u & behind & $<$ Du achter, E after \\
\hline ((n)a)bini & into, inside & $<$ Du binnen \\
\hline ((n)a)biti & outside & $<$ Du buiten \\
\hline ((n)a)bo(no) & on & $<$ Du boven \\
\hline afo $($ fa(n)) & in front of & $<$ na + Du voor \\
\hline ((n)a) molee & below & $<$ Du omlaag (dialectal) \\
\hline ((n)a)obu & onto, over & $<$ Du over \\
\hline ((n)a)ondə/-u & under & $<$ Du onder \\
\hline
\end{tabular}

Table 12.4: Locative prepositions with na.

3 See also [3231: 28 a gooi em na Meddel onder sender], where the locative noun is followed by the preposition onder, resulting in 'in the midst among them'. 


\subsection{Atlantic na and Possible Substrate Influence}

\subsubsection{Atlantic na}

As shown in (Boretzky 1983: 195) and further argued in detail in Corum (2015), there was a widely used Atlantic creole general locative preposition $n a$ in use. We find it in Portuguese lexifier creoles such as Principe and Guinée-Bissau, in Papiamentu, in the Surinamese creole cluster, as well as in VIDC. In Haitian, there is a form nã , but this may be derived from French dans [dã] 'in'. Very likely, the form was part of a number of the pidgins that were used in the Atlantic slave trade.

In the Surinam creole cluster and in VIDC this na may be combined with a locative element, as noted above, to mark a configurational locative. This possibility is absent in Papiamentu and in Haitian. However, the location of the locative element varies. It can be post-noun phrase, resulting in $[\mathrm{na}+\mathrm{NP}+\mathrm{X}]$, in Saramaccan and optionally in early Sranan, and pre-noun phrase, resulting in $[n a+X+N P]$ both in earlier and later Sranan and in all varieties of VIDC.

\subsubsection{Gbe}

Gbe adpositional phrases are head-initial, with prepositions preceding their complement (Aboh 2010: 227; see also Ameka 2003)). Aboh assumes a simple structure as in (05b):
a. Kòfi zé kwié xlán Àsíb
Kofi take-PERF money to Asib
'Kofi sent money to Asiba'
b. [PP [P xlán] [DP Àsíbá]]

While prepositions have a verbal origin, the class of locative postpositions has a nominal origin. In inland dialects the possessive marker $f e$ is required with them, but in coastal dialects this is absent. Thus the overall pattern is illustrated in (06):

(06) Akadí le $\quad \mathrm{kpl} \sim$ o-a (fé) ta.me

lamp be_at.PRES table-DEF (POSS) above

'The lamp is above the table.' (Ameka and Essegbey, 2006: 363).

\subsubsection{Akan}

In Akan the locative preposition (07b) also functions as a locative verb (07a):
a. ว-wว Eugene
3sg-be.at Eugene
'He is in Eugene.'
b. o hun no wo Eugene
ipl see 3 pl in
'We saw them in Eugene.' (Payne 1997: 87)

As a preposition, it cannot receive person marking.

In addition, there are postpositions to mark a specific configurational location:

(08) Ntoma no sen ahoma no so

Cloth DET hang rope DET TOP

'The cloth is/hangs on the clothes line.' (Ofori 2006: 156) 
(09) $\varepsilon$ dua no si asoredan no ho

tree DET sit church.house DET SIDE

'The tree is planted by the chapel.' (Owusu et al. 2015: 181)

\subsection{Dutch (17/18th c): Letters}

We will briefly mention a few aspects of locative preposition usage in Dutch, drawing on the corpus of captured letters.

\subsubsection{The Dutch System}

The Dutch adpositional system is far too complicated to describe here in any detail. There are at least three categories of elements involved:

- pre- or postpositions (where the latter are often directional in modern Dutch)

- adverbs, which are often morphologically complex (at least diachronically) and contain a be- prefix and an -en suffix.

- particles of the verb, which can be separated from it as the verb appears in second position

Some examples are given in Table 12.5 .

Particles will not be discussed further here (but see Muysken, van der Sluijs and Los, 2017). The adverbs may also be used prepositionally in modern Dutch, as well as functioning as free standing elements.

\subsubsection{Naar Boven in 18th Century Dutch}

One possibility is that naar boven in 18th century Dutch was a model for na bobo. It is often used directionally, as in (10) or translocationally, as in (11).

(10) zo dat wij (...) genootzaakt waaren na boven te gaan. so that we forced were to go

'so that we (...) were forced to go upstairs. (to the deck)

(Cape of Good Hope, May 31, 1781) NAAR + BOVEN: 'upstairs'

(11) ons leger met den Prins van orangie (...) is naer boven int our army with the Prince of Orange is to above in.the

Lant van keulen om de france daer te doen verhuijsen

Land of Cologne for the French there to make move

'Our army with the Prince of Orange (...) is up in the country of Cologne to make the French move there.' (Hoorn, November 30, 1672)

\begin{tabular}{|l|l|l|}
\hline Pre/postposition & adverb & particle \\
\hline op/over 'on' & boven 'above' & op-bellen 'phone' \\
\hline uit 'out' & buiten 'outside' & uit-steken 'stick out' \\
\hline in 'in' & binnen 'inside' & in-kopen 'to shop' \\
\hline & beneden 'beneath' & ne(d)er 'down' \\
\hline
\end{tabular}

Table 12.5: Simplified schematic overview of the Dutch adposition system. 


\subsubsection{The Preposition op in 18th Century Dutch}

The preposition $o p$ 'on' is frequently used, and may be a very general locative, as in the following two examples:

(12) Sr. Pieter Cnoll Coopman woonende in het
Sr. P. C. merchant residing in the
Fort op Batavia.
Fort on Batavia (Hoorn, 1672)
'Mr. Pieter Cnoll merchant residing in the Fort in Batavia.'
(13) Wiens vader predicant is in den classis van
whose father preacher is in the classis from
Alckmaer tot Egmont op zee
Alkmaar to Egmont on see (Hoorn, 1672)
'whose father is a preacher in the church region from Alkmaar to Egmont aan Zee.'

\subsection{VIDC (18th c)}

\subsubsection{The Earliest Sources}

In the materials of Von Zinzendorf (1739) we find standard Dutch examples such as (14), where boven is nominal:

(14) God zegen all met segen van boven

'God bless all with blessing from above.'

However, there are also some much more creole-like data. In the following na co-occurs with $o p$ in the same sentence, recalling the generalized $o p$ in the $18^{\text {th }}$ century letters:

(15) Die tyd mi a wes na Poppo op Africa

then 1sG PST be LOC Poppo on Africa

'Then I was in Poppo in Africa.'

In the first printed translation of the VIDC hymns (1765) we find the complex preposition that later became common. Notice this does not mean 'above of' here, but 'on'.

(16) Mee joe Sabbath na bovo die Stoel van joe Vader, with 2SG Sabbath LOC-ABOvE DET chair of 2sG Father

'With/and your Sabbath on the Chair of your Father'

However, we also find the simplex preposition boven:

(17) Noe Joe God bove allemaal, geloofd na Eewigheid!

now 2sG God above all praised LOC eternity

'Now you(r) God above all, praised in eternity!'

\subsubsection{VIDC: First Translation of Gospel Harmony (Before 1780)}

In the first translation of the Gospel Harmony (around 1773, before 1780) we find productive use of the complex preposition, sometimes used adverbially as a directional, as in (18), sometimes as a true preposition, as in (19) and (20). 
(18) Sender a loop na-boven na Jerusalem

3PL PST go LOC-above naar/LOC Jerusalem

'They went up to Jerusalem.' German source: hinauf

(19) Ons Tata sender a ka bed.aan na-boven deese Berg

1PL father 3PL PST PRF worship LOC-above this mountain

'Our fathers had worshipped on this mountain.' German source: auf

(20) maar a wees alltid Dag en Nacht na-bovo die Ber=g-en

but PST be always day and night LOC-above DET mountain-PL

'but ... was always day and night on the mountains.'

\subsubsection{VIDC 18th: op}

However, the translations also contain cases of the more Dutch-like preposition $o p$. In (21) and (22) it could be part of a fixed Dutch expression:

(21) Vor set ons Voet[- $\left.{ }^{\star} t^{\star}\right]$ sender op die Pad van Vrede (321:5) for put 1PL foot 3PL on DET path of peace

'to put our feet on the path of peace'

(22) eer die Mensch Soon sal sitt op die Troon (322:81)

before DET man son FUT sit on DET throne

'before the Son of Man shall sit on the Throne'

However, in (23) there is an apparent contrast between op, which is supra-locative, and the more general locative $n a$ :

(23) die a see: Op die Berg-en (na Rama) DET PST say on DET mountain-s LOC Rama

'He said: in the mountains at Rama.'

In some cases, there appears to be use of $o p$ as a calque on the German original auf in a translation:

(24) die a wees duis=ter op die Afgrond. (325a: 1)

3SG PST COP dark on DET abyss

'There was darkness above/in the abyss.' （Finster auf der Tiefe, Luther 1912)

\subsubsection{Variation in $18^{\text {th }}$ Century Use of Naboven}

There appears to be variation in the use of naboven in the $18^{\text {th }}$ century materials. The manuscript for the translation of the Old Testament (325, Job 20: 11), presented alternatives:

(25) En leei met em \{op|naboven $\}$ die Stof.

and lay with $3 \mathrm{sg}$ on|LOC.above DET dust

'and lay with him on the dust.'

The variation is of two kinds: variation in the forms encountered, and variation in the meaning of the expression. In the Gospel Harmony manuscripts 321 and 322 we find naboven, na boven, nabovo, na bovo, and in 3231 and 3232 naboven with the alternatives boven, boven op. 


\subsubsection{The Adverb/Preposition Boven in Later Texts}

In later texts we also find the use of bare boven, possibly under English influence:

(26) Wat ben boven die, dat ben van die Quaat

what COP above that, that COP from/of DET Evil (321:25)

'What is above of it, is from the Evil' (English Gospel Harmony, Lieberkühn 1771: 'cometh of Evil')

(27) Die Jünger no $\backslash$ ben boven si Baas

DET disciple NEG \COP above 3.POss master (321:25)

'The disciple is not above his master' (English Gospel Harmony 1771)

(28) en a staan boven over die Plaats

and PST stand above over DET place

'and stood above of the place' (3231: 7)

(English Gospel Harmony 1771: 'stood over where (...)')

\subsubsection{Distribution in Texts in the $18^{\text {th }}$ Century Materials}

The distribution of the locative prepositions is presented in Table 12.6.

It is striking that in these materials the most frequent locative marker, by far, is $o p$, both locational and directional. The combination na-boven and its variants is relatively infrequent, though more frequent in the earlier than in the later translations. Bare boven is not frequent, and is sometimes used adverbially. Bovenop always has a clear supra-locative interpretation in these materials.

It should be borne in mind that the general locative creole preposition $n a$ is much more frequent than these alternatives, as shown in Table 12.7:

\begin{tabular}{|l|c|c|c|c|c|c|}
\hline & locational & directional & adverbial & locational & directional & adverbial \\
\hline Before 1780 & \multicolumn{7}{|c|}{321} & \multicolumn{4}{|c|}{322} \\
\hline boven & 4 & - & 2 & 1 & - & 2 \\
\hline op & 21 & 12 & - & 23 & 5 & - \\
\hline bovenop & 1 & 2 & - & 0 & 1 & - \\
\hline na bovo, naboven & 3 & 3 & - & 7 & 4 & - \\
\hline $\mathbf{1 7 9 0 - 9 5}$ & 2 & - & 2 & 3 & - & 4 \\
\hline boven & 26 & 9 & - & 27 & 10 & - \\
\hline op & 2 & - & - & 2 & 1 & - \\
\hline bovenop & 1 & 2 & - & 2 & 3 & - \\
\hline na bovo, naboven & & & & & & \\
\hline
\end{tabular}

Table 12.6: The distribution of the locative prepositions in the $18^{\text {th }}$ century materials.

\begin{tabular}{|l|c|c|c|c|}
\hline & All $\boldsymbol{n a}$ & \#na\# $^{4}$ & \#na\# LOC & \#na\# DIR \\
\hline 321 (before 1780) & 940 & 511 & 109 & 79 \\
\hline 3232 (about 1795) & 972 & 558 & 34 & 68 \\
\hline
\end{tabular}

Table 12.7: The occurrence of locative $n a$ in some of the $18^{\text {th }}$ century materials.

4 The \# mark spaces is the original manuscript. 
The preposition $n a$ can be both locational and directional. In 3232 locative $n a$ is often replaced by in 'in' or $o p$ 'on'. The use of na should be studied separately because of its multifunctional use and high frequency.

\subsubsection{Alternatives in the Texts Used}

As pointed out in Van Rossem (2017), an interesting perspective on preposition choice in the $18^{\text {th }}$ century texts is gained from the practice of providing several alternatives, reflecting the struggle of the translators in choosing between different varieties, vernacular creole or more standard, and remaining faithful to the original text. An example is the following:

(29) $\mathrm{mi}$ Tegenparteyder fonk met $\mathrm{s}^{\star} \mathrm{i}^{\star} \quad$ Oogo $\{$ nalop $\}$ mi. (325c: Job 16)

1SG opponent sparkle with 3sG.POs eye LOC 1sG

'My adversary sparkles with his eyes upon me.'

(Luther 1912: funkelt mit seinen Augen auf mich)

Here the German original has auf and the translator is choosing between $o p$ and $n a^{5}$

Alternatives found are listed below. All appear only once in the entire Clarin-NEHOL Corpus, unless otherwise indicated.

$\begin{array}{ll}\text { op|met } & \text { op|na } \\ \text { na|op [6] } & \text { op|naboven } \\ \text { over|boven } & \text { tot|op } \\ \text { op|over } & \text { van|op } \\ \text { op|voor [2] } & \text { op|van }\end{array}$

The preposition $o p$ is often replaced by $n a$, but also by many other prepositions, suggesting its wide spread as an all purpose oblique in at least some varieties of $18^{\text {th }}$ century VIDC.

\subsection{The $20^{\text {th }}$ Century VIDC Materials}

\subsubsection{General Overview}

The main form in the texts collected by de Josselin de Jong (1926) (although there is considerable variation in the form) is supra-locative preposition(s) ((n)a)bo(no), besides the extremely frequent general locative and directional $n a$, of course. An example:

(30) mi ki ju sit abo də stul nou

1SG see 2SG sit on DET chair now

'I see you sitting on the chair now.'＜noBreak>（dJdJ 1926:67, Roberts)

Thus we find the following forms, as listed in Table 12.8

In Nelson (1936) only bo is found. ${ }^{6}$

There does not appear to be any functional specialization of any of these prepositional form variants. The main contrast with forms with or without preceding $(n) a$ ( $a$ has developed out of $n a$ )

5 Other examples are 321: 45: JESus a wees alleenig op die Land, en no a ka kom tot sender (na|op die Bood.)] [321: h.3: En Petrus a kik sterk op em met Johannes, en a see: Kik /op|na/ ons.] [325c: 67: En si Gebeenden moet betaal si verborgen $\mathrm{S}^{*} . . .{ }^{*}$ en leei met em \{op|naboven\} die Stof, where Luther has: und sie werden sich mit ihm in die Erde legen.

6 Den Besten and Van Rossem (2013): 15: on - bo, 909: Put something on the table[.+] </> - Du th'got bo th' tafl., 1127: Wipe your feet on the mat. - Fek yo fot bo di mat., 1129: The fowl (hen) is there on the roof of the house. $-D i$ hundu bin da bo di hus., 1130: It has flown upon the house. -Ka flik bo di hus 


\begin{tabular}{|l|l|l|l|}
\hline bo/bu & 142 & bono & 1 \\
\hline abo & 8 & nabono & 5 \\
\hline nabo & 2 & & \\
\hline
\end{tabular}

Table 12.8: Morpho-phonological variants of na bono in the $20^{\text {th }}$ century materials.

is with ${ }^{*} n a>a$. The preposition [a] marks location in a broad sense, and goal in a broad sense, [bo] marks supralocation. ${ }^{7}$ A further indication that there is no functional specialization of individual form variants is the finding that they alternate in a wide variety of contexts, including cases where they co-occur idiomatically with specific predicates, such as wak 'wait':

(31) bli da staan werán lo wak bo Bru Hon stay there stand again IPFV wait on brother dog '[he] stopped there again, waiting for Brother Dog'

(dJdJ 1926:51, Roberts) (cf. Du wachten op)

(32) ju kaa listáá mi lo wak nabono ju 2SG PRF let 1SG IPFV wait on 2SG

'You have kept me waiting for you.'

$$
\text { (dJd 1926:25, Prince) }
$$

Rather, there is individual variation, since Prince is the only one of De Josselin de Jong's nine informants to use nabono and uses it wherever others use $(a) b o$

The items $o p$ ( $<$ Du op) and abobo ( $<$ Du boven) occur as adverbs as well. Furthermore, op can occur as a particle, so that we can double $o p$ :

(33) Di kabái a lep op op a himúl.

Motion

DET horse PST leap up up LOC sky

'The horse leapt up towards the sky.' (dJdJ 1926:15, Joshua)

(34) jaa, ju kaa ho, wa də here abobo kaa see: Motion/location

yes 2SG PRF hear what DET lord above PRF say

'Yes, you heard, what the Lord above said' (dJdJ 1926:52, Roberts)

Note that the two are different in meaning $O p$ is always upwards motion/direction; abobo can be used for both.

As noted, $o p$ often occurs as a verb particle, in the case of dink op 'remember', 'think of', $o p$ has fused with the verb and phonologically eroded; but also newly replaced by bo 'on':

(35) Ham see, am nə kam dingkóó.

3SG say 3SG NEG can remember

'He said, he could not remember.'

(dJdJ 1926:18)

(36) di frou parat a fraa di man as am nu kan

DET woman parrot PST ask DET man if 3SG NEG can

ding bo weni

think on when

7 Den Besten (letter den Besten, 2 November 1993, see also Den Besten and Van Rossem 2013): “Isabella Sylvester's $b o$ in the sense of 'on (the roof of) ' and 'upon' in two sentences said by her, however, most probably does not reflect Danish paa (på). It derives from Dutch boven via Creole Dutch abo/abobo/nabobo, which consists of the all-purpose locative preposition na and bobo (from Du. boven)."

8 In the 18th century materials we find dink op na or dink op: [321: 5: en vor dink na si heilig Verbond], [322: 5: en dink op na si heilig Verbond], [3232: 5: en a dink op na Si heilig Verbond]. 
'The female parrot asked the male one if he could not think of/remember when...' (dJd 1926:41)

\subsubsection{Expression of Source:}

While the element na has many locative uses, it cannot be used as an expression of source by itself. By contrast $f a(n)$ can:

(37) Ju fo bli een jaa mi ons fo ju nee amfa ons $2 s \mathrm{sg}$ mod stay one year with $1 \mathrm{PL}$ before $2 \mathrm{sg}$ take $3 \mathrm{sg}$ of $1 \mathrm{PL}$

You must stay with us for one year before you take her from us.' (dJdJ 1926:14, Joshua)

The combination $f a$ bo can mark supralocational source:

(38) $\mathrm{A}^{\mathrm{n}}$ no kan kri di jung fa boo shi rigí. 3SG NEG mod getDET boy of on 3s.poss back

'It [a horse] couldn't get the boy from his back.' (dJdJ 1926:15, Joshua)

Finally, there also be an elative meaning added in (it) $\mathrm{fa}$ bo:

(39) Fo ma se paséé di wurum kri teki sinpiwiri, COMPL make say pass DET worm get piece aloe.vera shini di hopo a twee, krou alma di grun slim it $\underline{\text { a }} \underline{\text { bo }}$ di. cut 3.INAN open LOC two scratch all DET green slime out of on 3.INAN 'To make the worms go away, get a piece of aloe vera, cut it open in two, scratch all the green slime out of it.'

(dJdJ 1926:66)

\subsubsection{Distribution in Texts in the $20^{\text {th }}$ Century Materials}

Table 12.9 gives an overview of the distribution in the materials of De Josselin de Jong (1926):

It is clear that the form $o p$, which is so common in the $18^{\text {th }}$ century materials, is no longer used as a preposition. Variants of na bono are now just about the only forms used. It is clear that the wide variety of morpho-phonological variants of na bono is also reflected at the individual level

Table 12.10 presents use of the supra-locative prepositions in dJdJ 1926 per speaker, showing that there was considerable variation (Van Sluijs 2016).

\subsection{Discussion, Conclusions and Suggestions for Further Research}

The general use of reduced variants of na bono in the $20^{\text {th }}$ century materials, to the detriment of $o p$ and boven, which were used with some frequency in the $18^{\text {th }}$ century texts, attests to the strong influence that the Atlantic pidgin and the West African languages had in the genesis of VIDC in its vernacular form used by the descendants of the enslaved Africans. The Atlantic pidgin contributed the general use of $n a$, which is pervasive in VIDC, while the West African languages contributed the combination of $n a$ with a specific location marker to indicate configurational supra-location. The Dutch strong form boven and the generalized vernacular Dutch location marker $o p$ all but disappeared in the $20^{\text {th }}$ century materials, and only survived as adverbs or verb particles 


\begin{tabular}{|l|c|c|c|c|c|}
\hline & locational & & directional & adverbial & particle \\
\hline & + config & - config & & & \\
\hline$O p$ & - & - & $(2)^{9}$ & $1^{10}$ & $30^{11}$ \\
\hline$((n) a) b o(n o)$ & 35 & 6 & 104 & - & - \\
\hline Bobu & - & - & 2 & - & - \\
\hline Abobo & - & - & - & 9 & - \\
\hline
\end{tabular}

Table 12.9: Distribution of supra-locative prepositions in the $20^{\text {th }}$ century materials.

\begin{tabular}{|l|c|c|c|c|c|c|c|c|c|c|c|}
\hline & $b o$ & & & (it) fa bo & $*$ & $(n) a b o$ & $* *$ & & (na)bono & & bobu \\
\hline & + dir & - dir & - dir & - dir & - dir & +dir & - dir & - dir & +dir & - dir & + dir \\
\hline & & + con & - con & + con & - con & & +con & - con & & -con & \\
\hline Joshua & 41 & 8 & 1 & 4 & 1 & 1 & - & - & 1 & - & - \\
\hline Prince*** & - & - & - & - & - & - & - & - & 1 & 2 & - \\
\hline Testamark & 5 & 3 & - & - & - & - & 1 & - & - & - & - \\
\hline T'mark/X & 1 & - & 1 & 1 & 2 & - & - & 2 & - & - & - \\
\hline Joseph & 1 & - & - & - & - & - & - & - & - & - & - \\
\hline Christian & - & - & - & - & - & - & 1 & - & - & - & 1 \\
\hline Roberts & 51 & 20 & & 1 & - & 2 & 2 & - & - & - & 1 \\
\hline
\end{tabular}

*Joshua uses $f a b o$, Testamark/X and Roberts it $f a b o$

** Testamark and Roberts each use nabo once

*** Joshua uses bono, Prince nabono

Table 12.10: Use of the supra-locative prepositions in the $20^{\text {th }}$ century materials per speaker.

Thus, from the available forms in the original feature pool, only a few elements survived as prepositions. It requires detailed analysis to see whether all these forms were really part of the creole in the first place, or simply impositions from European languages by the missionaries, and whether the vernacular Dutch of the Virgin Islands was clearly separate from the creole (Van Rossem 2017).

Even the article length discussion of a singular construction, supra-locative prepositions, barely does justice to the data. Much more needs to be said about the specific meanings conveyed, and the philological interpretation of the material. It would also be useful to consider the other configurational prepositions involving $n a+$ location. Do they show the same patterns of adaptation and selection as nabono?

Casting the net even wider, it would be very interesting to compare the data in VIDC with partly similar, partly different developments in other creole languages, including Berbice Dutch Creole, the Surinam Creole cluster, and Papiamentu.

9 There are two cases where op is indeterminate/ambiguous between being a directional preposition, or a verb particle.

10 Here, op is followed by/co-occurs with a directional AP headed by preposition $a$, and as a whole follows op as a verb particle expressing upwards motion. As an adverb, op could be said to be some kind of reduplication.

11 In six of the thirty occurrences of op as a verb particle, it expresses upwards motion, just as English 'up' (as in 'he jumped up'). In the other twenty-four occurrences op occurs in more or less idiomatic expressions, such as hou op 'stop' (< Dutch hou op 'stop', lit. hold up), tu op 'put away, store' (lit., 'close up'; tu 'çlose' < Dutch toe 'closed'), fin op mi 'encounter' (lit. 'find up with'), and cases where op has a destructive meaning, as in ru op "wreck up", skee op "tear up", sni op "cut up", trample op "trample up". 


\section{Acknowledgements}

We are grateful for the comments of the participants in the The Structure, Emergence and Evolution of Pidgin and Creole Languages meeting at the University of Amsterdam on December 14, 2015, in particular Enoch Aboh, Adrienne Bruyn, and Anne Zribi-Hertz., and for the anonymous reviews. The NEHOL database has been created in collaboration with the MPI Nijmegen, one of the CLARIN centres in the Netherlands, thanks to the CLARIN-NL-10-010 grant for the NEHOL project (www.clarin.nl/node/162). The NEHOL database is accessible at http://corpus1.mpi.nl/. The metadata and the actual data of the NEHOL database can also be accessed from the CLARIN Virtual Language Observatory: http://catalog.clarin.eu/vlo/search?fq=collection:TLA:+NEHOL

\section{References}

Aboh, E 2010 The P route. In G Cinque and L Rizzi (eds.) Mapping spatial PPs (The cartography of syntactic structures, 6. New York: Oxford University Press. Pp. 225-260.

Adams Graves, A V 1977 The present state of Dutch creole of the Virgin Islands. Ann Arbor, Michigan: University Microfilms.

Ameka, F K 2003. Prepositions and postpositions in Ewe: empirical and theoretical considerations. In A Zibri-Hetz and P Sauzet (eds.) Typologie des langues d'Afrique et universaux de la grammaire. Paris: L'Harmattan. Pp. 43-66.

Ameka, F K and J Essegbey. 2006. Elements of the grammar of space in Ewe. In SC Levinson and DP Wilkins (eds.) Grammars of Space: Explorations in Cognitive Diversity. Cambridge: Cambridge University Press. Pp. 359-398.

Bakker, P 2014 Three Dutch Creoles in Comparison. Journal of Germanic Linguistics 26(3), 191-222.

Besten, $\mathrm{H}$ den and C van Rossem. 2013. Diplomatische editie van de Negerhollandse woordenlijsten van Frank G. Nelson. Tijdschrift voor Nederlandse Taal- en Letterkunde 130(1). Digital addendum.

Boretzky, N 1983 Kreolsprachen, Substrate und Sprachwandel [Creole languages, substrates and language change]. Wiesbaden: Harrasowitz.

Corum, M 2015 Substrate and adstrate: The origins of spatial semantics in West African Pidgincreoles. Boston: Mouton de Gruyter.

Hesseling, D C 1905 Het Negerhollands der Deense Antillen. Bijdrage tot de geschiedenis der Nederlandse taal in Amerika. Leiden: Sijthoff.

Josselin de Jong, J P B de 1926 Het huidige Negerhollandsch (teksten en woordenlijst). Verhandelingen der Koninklijke Academie van Wetenschappen te Amsterdam, Nieuwe Reeks, Deel 26, no. 1. 124.

Lieberkühn, S 1771 The Harmony of the four Gospels, or, the history of our Lord and Saviour Jesus Christ (...) English version. London.

Luther, M 1912 Die Bibel oder die ganze Heilige Schrift des Alten und Neuen Testaments. Revidierte Fassung der deutschen Übersetzung Martin Luthers. Stuttgart.

Mufwene, S 2001 The ecology of language evolution. Cambridge: Cambridge University Press.

Muysken, P 1995 Studying variation in older texts: Negerhollands. Column for the Journal of Pidgin and Creole Languages 10: 335-348.

Muysken, P, R van Sluijs and B Los 2017 Verb particle combinations in Dutch - the lexifier language for several Caribbean creole languages - Papiamentu, and the languages of Surinam: evidence for word order change? Los, B. \& P. de Haan (eds.) Word Order Change in Acquisition and Language Contact: Essays in Honour of Ans van Kemenade. Amsterdam: Benjamins. 
Nelson, F G 1936 Virgin Island Dutch Creole Word List. Published in Den Besten and Van Rossem (2013).

Ofori, S A 2006 Topics in Akan grammar. Doctoral dissertation, Indiana University, Bloomington. University Microfilms.

Oldendorp, C G A 1777 C.G.A. Oldendorps Geschichte der Mission der evangelischen Brueder auf den caraibischen Inseln S. Thomas, S. Croix und S. Jan. Herausgegeben durch Johannes Jakob Bossart. Barby, Virgin Islands: Christian Friedrich Laur.

Oldendorp, C G A 2000 Historie der caribischen Inseln Sanct Thomas, Sanct Crux und Sanct Jan, insbesondere der dasigen Neger und der Mission der evangelischen Brüder under derselben. Erster Teil. Kommentierte Ausgabe des vollständigen Manuskriptes aus dem Archiv der Evangelischen Brüder-Unität Herrnhut. Ediert von Hartmut Beck, Gudrun Meier, Stephan Palmié, Peter Stein und Horst Ulbricht. [Abhandlungen und Berichte des Staatlichen Museums für Völkerkunde Dresden, Bd. 51 des Gesamtw.: Monographien; 9]. Berlin: VWB, Verlag für Wiss. und Bildung.

Owusu, E, J Agor, A Adade-Yeboah, K Dovlo 2015 Basic Locative Constructions and Simple Clause Structures of English, Akan, and Safaliba. International Journal of Language and Linguistics 2(5): $178-191$.

Payne, T E 1997 Describing morphosyntax: a guide for field linguists. Cambridge: Cambridge University Press.

Reinecke, J E 1937 The Negro Dutch of the Danish Antilles. Marginal languages: a sociological survey of the creole languages and trade jargons. Unpublished thesis (PhD), Yale University. Pp. 394-425.

Rossem, C van 2017 The Virgin Islands Dutch Creole Textual Heritage: Philological Perspectives on Authenticity and Audience Design. Unpublished thesis (PhD), Radboud University.

Rossem, C van and H van der Voort (eds) 1996 Die Creol Taal, 250 Years of Negerhollands Texts. Amsterdam: Amsterdam University Press.

Rutten, G and M J van der Wal. 2014. Letters as Loot, A Sociolinguistic Approach to Seventeenthand Eighteenth-Century Dutch. Amsterdam/Philadelphia: John Benjamins.

Sabino, R 1990 Towards a Phonology of Negerhollands: An Analysis of Phonological Variation. Unpublished thesis (PhD), University of Pennsylvania.

Sabino, R 2012 Language Contact in the Danish West Indies: Giving Jack His Jacket. Leiden, NL: Brill.

Sluijs, R van. 2016 Variation and Change in Virgin Islands Dutch Creole: Tense, Modality and Aspect. Unpublished thesis (PhD), Radboud University.

Sluijs, R van, M van den Berg, and P Muysken 2016 Exploring genealogical blends: the Surinamese Creole Cluster and the Virgin Island Dutch Creole Cluster. Lingua doi:10.1016/j.lingua.2015.12.004.

Sprauve, GA 1976 Chronological implications of discontinuity in spoken and written Dutch Creole. New directions in creole studies. G. Cave, ed. Georgetown: Society for Caribbean Linguistics.

Stein, P 1986 The Documents concerning the Negro-Dutch Language of the Danish Virgin Islands, St. Thomas, St. Croix, and St. John - Negerhollands -, in the Unitäts-Archiv (Archives of the Moravian Brethren) at Herrnhut. A Commented Bibliography. Papers on Negerhollands, the Dutch Creole of the Virgin Islands. Amsterdam Creole Studies IX. H. den Besten ed. Amsterdam: Publikaties van het Instituut voor Algemene Taalwetenschap 51, 19-31.

Stein, P and H van der Voort (eds.) 1996 Christian Georg Andreas OLDENDORP, Criolisches Wörterbuch. Erster zu vermehrender und wo nöthig zu verbessernder Versuch [1767/68], herausgegeben, eingeleitet und mit Anmerkungen versehen von Peter Stein, sowie das anonyme, J.C. KINGO zugeschriebene Vestindisk Glossarium, herausgegeben, eingeleitet und mit Anmerkungen versehen von Hein van der Voort, Lexicographica, series maior 69. Tübingen: Max Niemeyer Verlag. 
Vandeloise, C 1991 Spatial Prepositions: A Case Study in French. Chicago: The University of Chicago Press.

Vandeloise, C 1994 Methodology and analyses of the preposition in. Cognitive Linguistics 5: 157-184.

Zribi-Hertz, A 1984 Orphan Prepositions in French and Concept of Null Pronoun. Bloomington. IN: Indiana University Linguistics Club.

Zribi-Hertz, A and Loïc, J-L 2015 General Locative Forms in (two) creoles (Haitian, Martinican) (SEEPiCLa), University of Amsterdam, December $14^{\text {th }}-15^{\text {th }}, 2015$.

Zwarts, J 1997 Lexical and functional prepositions. In D Haumann and S J Schierholz, (eds.), Lexikalische und grammatische Eigenschaften präpositionaler Elemente Tübingen: Max Niemeyer Verlag. Pp. 1-18.

\section{Digital Sources}

http://brievenalsbuit.inl.nl/The Letters as Loot/ Brieven als Buit corpus. Leiden University. Compiled by Marijke van der Wal (Programme leader), Gijsbert Rutten, Judith Nobels and Tanja Simons, with the assistance of volunteers of the Leiden-based Wikiscripta Neerlandica transcription project, and lemmatised, tagged and provided with search facilities by the Institute for Dutch Lexicology (INL). 2nd release 2015.

http://www.gekaaptebrieven.nl/ Meertens Institute. Compiled by N. van der Sijs (Programme leader), with the assistance of volunteers.

Luther 1912: http://www.bibel-online.net/ 